\title{
Resistant bacteria in society
}

Citation for published version (APA):

Kamenshchikova, A. (2020). Resistant bacteria in society: Travelling through practices of policy, healthcare and science. [Doctoral Thesis, Maastricht University]. Maastricht University. https://doi.org/10.26481/dis.20201021ak

Document status and date:

Published: 01/01/2020

DOI:

10.26481/dis.20201021ak

Document Version:

Publisher's PDF, also known as Version of record

\section{Please check the document version of this publication:}

- A submitted manuscript is the version of the article upon submission and before peer-review. There can be important differences between the submitted version and the official published version of record.

People interested in the research are advised to contact the author for the final version of the publication, or visit the DOI to the publisher's website.

- The final author version and the galley proof are versions of the publication after peer review.

- The final published version features the final layout of the paper including the volume, issue and page numbers.

Link to publication

\footnotetext{
General rights rights.

- You may freely distribute the URL identifying the publication in the public portal. please follow below link for the End User Agreement:

www.umlib.nl/taverne-license

Take down policy

If you believe that this document breaches copyright please contact us at:

repository@maastrichtuniversity.nl

providing details and we will investigate your claim.
}

Copyright and moral rights for the publications made accessible in the public portal are retained by the authors and/or other copyright owners and it is a condition of accessing publications that users recognise and abide by the legal requirements associated with these

- Users may download and print one copy of any publication from the public portal for the purpose of private study or research.

- You may not further distribute the material or use it for any profit-making activity or commercial gain

If the publication is distributed under the terms of Article $25 \mathrm{fa}$ of the Dutch Copyright Act, indicated by the "Taverne" license above, 


\section{SUMMARY}

Introduction. Antimicrobial resistance (AMR) is a growing public health concern globally that calls for comprehensive transdisciplinary approaches. Although AMR refers to biological mechanisms of bacterial resistance, it is a deeply social phenomenon that is influenced by economic, political and cultural processes. Studies in microbiology have provided important insights into the biology of bacteria and their different ways of acquiring resistance. In turn, studies in social sciences have shown how antibiotic-related practices, including prescription, use, production as well as utilisation of antibiotic waste may influence the development of AMR. In this thesis, I took a step forward from studying antibiotic-related practices and analysed how AMR is incorporated and practised in different settings of policy, healthcare and science, and what kind of reality is constructed through these practices.

This thesis is a report of my journey through settings where I studied how AMR has been changing the social worlds of different actors. These settings included the world of international policy regulations on AMR and One Health approach to it; the world of public health AMR screening of refugees in the Netherlands; the world of antibiotic practices among medical doctors, pharmacists and patients in Russia; and the world of science with its diverse metaphors and methods to address AMR. The different chapters of this thesis elaborate on my findings from the journeys to each of the social worlds and their practices.

Chapter 1 analyses the policy world of AMR where the One Health approach has been gaining popularity since the publication of the Global Action Plan on AMR in 2015. Analysing international policy regulations on AMR, as well as more general health regulations from which AMR documents are derived, this chapter reflects on how the One Health approach shapes AMR in the international policy arena. Policy documents are understood here as performative - they are not simply describing the reality about AMR and One Health approach to it, but they construct this reality and influence practices of individuals involved in the human, animal and environmental sectors. The chapter engages with the theories of post-humanism to critically examine the modes of relations between the human, animal and environmental sectors that One Health approach to AMR proposes. It shows that despite the One Health ideal to build inter-sectorial collaborations for addressing shared health concerns, AMR policy regulations that implement One Health shape hierarchies between the health of different species and between knowledge practices of professionals working with these species.

Chapter 2 shifts the focus from the policy arena to public health practices of AMR screening of refugees in the Netherlands. This chapter analyses how AMR has been constructed 
as a potential risk posed by the incoming refugees. Focusing on different perspectives of microbiologists, public health doctors, public health nurses and refugees, AMR screening is shown to be a constructed phenomenon that can be understood as either a necessary public health measure, an unnecessary stigmatising technique, or a potential for the improvement of personal health. While the debates about the necessity of AMR screening of refugees have been taken place on the pages of scientific journals, this chapter reflects on a different question: how to perform an AMR screening of refugees to accommodate the diverse perspectives of different actors? The chapter is arguing for the need for co-production processes in developing and implementing the technique of screening, where the public health needs and potential risks of stigmatisations are equally considered.

Chapter 3 moves from the world of public health in the Netherlands to the world of healthcare practices in Russia. This chapter analyses antibiotic practices of medical doctors, pharmacists and patients against the background of the recently introduced policy requirement for the medical prescription on antibiotics. While this requirement aims to tackle the over-thecounter sale of antibiotics defining AMR as a problem of self-treatment, the chapter provides a more nuanced reflection on how AMR is practised and how antibiotic care is organised in Russia. Self-treatment practices with antibiotics are the results of different processes, including the lack of medical personal in the clinical settings that hiders a timely provision of care, and the inability of many patients to take time off work to visit a medical doctor. Recognising these different processes, medical doctors, pharmacists and patients adopt informal techniques to deliver and access antibiotics beyond the policy requirement for medical prescription. The chapter analyses these informal techniques as compensatory responses of healthcare professionals to the gaps in the official healthcare system.

Chapter 4 focuses on how microbiologists imagine AMR as a global phenomenon, which can be transmitted and disseminated from one country to another. Analysing metaphors that microbiologists use in their scientific articles on AMR and travelling, this chapter shows how the notion of global is presented in a very specific way. Using such metaphors as AMR 'reservoirs' and bacterial 'intruders', the metaphors in microbiology imagine the global transmission of AMR as a linear process where bacteria from low-income countries are transmitted to high-income countries with 'better hygiene'. The chapter argues that metaphors are not just figures of speech, but they help in navigating scientific research processes. Describing certain countries as AMR reservoirs and other countries as those with better hygiene may lead to the one-sided research processes, where the potential transmission of AMR from incoming travellers to countries-reservoirs is overlooked as less significant. 
Chapter 5 describes an experimental methodology 'stool and stories' that was developed by Maastricht University team to study AMR as a biosocial phenomenon. Following the cohort of graduate students who travelled from different parts of the world to India, this chapter brings together the data from microbiological stool sample analysis and the data from semi-structured interviews conducted with the same cohort. The two diverse sets of data focus on the same research question about the importance of AMR for international travelling but give different answers to this question. While microbiology highlights the potential risks for acquiring AMR when travelling internationally, social science data shows that travellers themselves do not consider AMR to be a relevant health problem in the context of travelling. This difference in answers demonstrates the important gap between the biological and social constructions of AMR, which are currently not connected.

Chapter 6 is a short reflection on my $\mathrm{PhD}$ journey as a transdisciplinary practice. This reflection argues for the infrastructural changes in the current ways of organising knowledge production practices that separate biomedical and social science approaches to AMR. Rather, the collaborative platforms, including academic journal and conferences, and transdisciplinary funding for understanding AMR should be established and promoted at the national and international levels.

General discussion and conclusion. The six chapters of this thesis focus on different settings and various practices of AMR. This diversity highlights that AMR is not a static and universal phenomenon that can be addressed in a similar way regardless of the context. On the contrary, the different insights from each of the chapters show that AMR acts and is acted upon in various ways depending on the hierarchies between different species and disciplines, the perceptions of risks, the available opportunities for treatment, and the language and methods of scientists who analyse and address AMR.

Departing from the analysis of antibiotic practices and focusing on how AMR is practised in different settings, this thesis offers an alternative analytical and political shift in understanding this phenomenon. It is a shift from antibiotics as a leading focus for understanding social and political processes related to AMR, to bacteria and changes that they introduce to social where they are situated. This shift allows for the understanding of AMR beyond antibiotic-related practices, AMR is analysed as constructed through the language of scientists and as a part of the daily reality of travelling and human mobilities. This has also political implications as it requires a change in the paradigm where social worlds with their daily practices of travelling, healthcare and farming have to be adapted to the biological mechanisms of bacteria, rather than to the opportunities offered by antibiotics. 
Appendices

\section{SAMENVATTING}

Inleiding. Antimicrobiële resistentie (AMR) is wereldwijd een groeiend probleem voor de volksgezondheid dat vraagt om een transdisciplinaire benadering. Microbiologische studies hebben belangrijke inzichten geleverd in de verschillende manieren waarop bacteriën resistentie verwerven. Onderzoek in de sociale wetenschappen heeft op haar beurt aangetoond hoe sociale-, politieke- en economische processen antibiotica productie, gebruik, en afval beïnvloeden en daardoor de ontwikkeling van AMR bevorderen dan wel remmen. Tegen de achtergrond van dit onderzoek heb ik geanalyseerd hoe AMR wordt geconstrueerd in verschillende settingen - beleid, gezondheidszorg en wetenschap. Het proefschrift is als het ware een verslag van mijn reis door deze verschillende werelden van AMR. Ik bestudeerde de ontwikkeling van de One Health-aanpak in de internationale beleidsarena; perspectieven op AMR-screening van vluchtelingen in Nederland in het kader van de volksgezondheid; omgang met antibiotica-richtlijnen door artsen, apothekers en patiënten in Rusland; en het gebruik van metaforen in microbiologisch onderzoek naar de relatie tussen AMR en internationaal reisgedrag. De verschillende hoofdstukken van dit proefschrift zijn een verslag van mijn reis naar een van deze werelden.

Hoofdstuk 1 analyseert de beleidsarena waarin de One Health-aanpak, die sinds de publicatie van het Global Action Plan on AMR in 2015 aan populariteit wint, werd ontwikkeld. Ik analyseer de internationale beleidsdocumenten op het gebied van AMR en het internationale gezondheidsbeleid waarvan AMR-documenten zijn afgeleid, en bekijk hoe de One Healthaanpak voor AMR in deze documenten wordt vormgegeven. Beleidsdocumenten worden hier opgevat als performatief - ze beschrijven niet alleen de realiteit over AMR maar ze construeren deze realiteit en ook de handelingspersdpectieven van betrokkenen uit de gezondheidszorg, de veeteelt en de milieusector. Het hoofdstuk gebruikt theorieën van het post-humanisme om de relaties tussen deze sectoren in de One Health-benadering van AMR kritisch te onderzoeken.

De analyse laat zien dat de One Health-benadering voor de aanpak van AMR, ondanks de doelstelling om intersectoraal te werken, impliciet hiërarchieën creëert tussen de gezondheid van mensen, dieren en ecosystemen, en ook tussen professionals die in deze domeinen werken. De gezondheid van mensen wordt als het meest centrale probleem gezien, en de andere sectoren moeten bijdragen aan de oplossing ervan. De gezondheid van dieren, gedomesticeerd en wild, en van het ruimere milieu verschijnt onbedoeld als ondergeschikt aan dat van mensen.

Hoofdstuk 2 verschuift de focus van de beleidsarena naar de volksgezondheid, en onderzoekt perspectieven op AMR-screening van vluchtelingen in Nederland. De 
vluchtelingen crisis leidt in 2015 zichtbaar in Europa tot discussies over nut en dilemma's van AMR-screening van vluchtelingen. Tegen de achtergrond van deze discussies heb ik verschillende perspectieven op de mogelijke constructie van vluchtelingen als een gezondheidsrisico onderzocht. Ik heb interviews gedaan met microbiologen, volksgezondheidsartsen, verpleegkundigen en vluchtelingen, en het blijkt dat AMR-screening vanuit hun perspectieven een verschillende betekenis krijgt. Microbiologen en artsen werkzaam in de publieke gezondheidszorg zien screening als een noodzakelijke maatregel in het kader van het onderzoek naar de volksgezondheid, verpleegkundigen zien het als een onnodige stigmatiserende interventie die weinig bijdraagt aan de volksgezondheid, en veel vluchtelingen zien screening als een potentiele techniek voor verbetering van de persoonlijke gezondheid en als er geen individuele uitslagen worden gegeven zien zij het over stigmatiserend. Terwijl de debatten over de noodzaak van AMR-screening van vluchtelingen primair een debat was van microbiologen in wetenschappelijke tijdschriften, heb ik geprobeerd de actoren te onderzoeken die er in de praktijk mee te maken zouden kunnen krijgen. Het hoofdstuk pleit voor meer samenwerking bij de ontwikkeling en implementatie van de screening, waarbij volksgezondheidsrisico's en risico's van stigmatisering beide worden gewogen.

In hoofdstuk 3 gaat de reis verder naar de wereld van de gezondheidszorg, en wel de gezondheidszorg in Rusland. Rusland is een interessante setting omdat recentelijk maatregelen zijn getroffen om wetgeving die antibiotica gebruik zonder doktersvoorschrift tegen moet gaan, te gaan implementeren en handhaven. Tot voor kort konden mensen antibiotica bij de apotheker halen: aan deze vorm van 'zelfmedicatie' moet nu een einde komen. We hebben interviews gedaan met artsen, apothekers en patiënten om te onderzoeken hoe zij omgaan met deze eis van antibioticagebruik op medisch voorschrift. De analyse geeft een reflectieve blik op de organisatie van antibioticagebruik en zorg voor bacteriële infecties in Rusland. De zogenaamde zelfmedicatie met antibiotica moet begrepen worden in de specifiek Russische context die gekarakteriseerd wordt door gebrek aan medisch personeel in de klinische setting, lange wachttijden, de gebrekkige mogelijkheden van veel patiënten om vrijaf te nemen en dus inkomen te derven om een arts te bezoeken. Omdat iedereen dit weet en artsen toch 'goede zorg' willen leveren, ontstaan er informele infrastructurele antibiotica praktijken om ' 'het verplichte recept'" werkbaar te maken. Dokters schrijven recepten voor een langere duur, voor het geval dat de klachten verergeren, of een hogere dosis zodat patiënten vooruit kunnen. Deze informele praktijken compenseren de hiaten en de problemen in de formele gezondheidszorg. 
Hoofdstuk 4 analyseert metaforen die microbiologen gebruiken om hun wetenschappelijk onderzoek over AMR en reizen te presenteren. Metaforen zijn interessant omdat ze geen onschuldige beeldspraken zijn, maar verbeeldingen van de realiteit en als zodanig een basis om te handelen. Metaforen geven als theoretische concepten richting aan wetenschappelijk onderzoek, ook aan disciplines die het imago hebben dat ze 'de natuur' representeren. Ook in deze disciplines speelt taal echter een sleutelrol in de verbeelding van onderzoeksresultaten. Voor de analyse heb ik een specifieke set belangrijke wetenschappelijke artikelen van microbiologen onder de loep genomen. De analyse laat zien dat onderzoekers met behulp van metaforen als AMR 'reservoirs' en bacteriële 'indringers', de overdracht van AMR op wereldschaal schetsen als een proces waar gevaarlijke bacteriën uit lage-inkomenslanden worden overgedragen aan landen met een hoog inkomen met een 'betere hygiëne. Hiermee worden landen impliciet als 'goed' en 'slecht' voorgesteld. Het beschrijven van bepaalde landen als AMR-reservoirs en andere landen als landen met een betere hygiëne, leidt er toe dat de overdracht van AMR van inkomende reizigers naar deze landen-reservoirs minder aandacht krijgt. Ook worden landen als homogene entiteiten voorgesteld terwijl grensgebieden bijvoorbeeld vaak andere patronen laten zien. De conclusie luidt dat het belangrijk is om te reflecteren op metaforisch gebruik van kernconcepten in AMR onderzoek en wat zij doen in beeldvorming en in de verdere ontwikkeling van onderzoek, omdat ze impliciet sommige zaken naar de voorgrond en de achtergrond duwen.

Als onderzoeksteam zijn we overtuigd van de waarde van transdisciplinair onderzoek naar AMR. Hoofdstuk 5 beschrijft het gebruik van een experimentele transdisciplinaire methodologie 'stool and stories' die we hebben ontwikkeld om AMR te bestuderen als een biosociaal fenomeen. Dit hoofdstuk presenteert de microbiologische analyse van ontlastingsmonsters en de sociologische analyse van semi-gestructureerde interviews, beide uitgevoerd binnen een cohort van studenten die de Global Health master volgden en uit verschillende delen van de wereld naar India reisden voor een symposium. De twee verschillende datasets richten zich op dezelfde onderzoeksvraag over het belang van AMR voor internationale reizen, maar geven verschillende antwoorden op deze vraag. Terwijl de microbiologische analyse (stool) laat zien hoe internationaal reizen samenhangt met het verwerven van AMR, toont de sociale wetenschappelijke analyse (stories) dat reizigers zelf AMR niet als een relevant gezondheidsrisico van reizen beschouwen. Dit verschil wijst erop dat de biologische en sociale constructies van AMR - ook in een cohort van hoogopgeleide en in de gezondheidsdisciplines geschoolde studenten - niet met elkaar verbonden zijn. De 
conclusie is dat het voor een beter begrip van AMR en AMR-preventie noodzakelijk is dergelijke verschillende resultaten met elkaar in dialoog te brengen.

Hoofdstuk 6 is een korte reflectie op mijn promotietraject als een transdisciplinair onderzoek. Deze reflectie pleit voor infrastructurele veranderingen in de huidige organisatie van het AMR-onderzoek, waarbij biomedische en sociaalwetenschappelijke benaderingen van AMR sterk gescheiden zijn. In plaats daarvan moeten er transdisciplinaire samenwerkingsplatforms, wetenschappelijke tijdschriften, conferenties, en financieringsvormen gecreëerd worden op nationaal en internationaal niveau, om AMR te begrijpen.

Discussie en conclusie. De zes hoofdstukken van dit proefschrift laten zien dat AMR niet een ding is, maar in verschillende contexten als een ander fenomeen wordt geconstrueerd, en op verschillende manieren wordt behandeld: de aanpak van AMR wordt uitgedrukt in termen van hiërarchieën tussen soorten, sectoren en disciplines, risico's voor gezondheid en voor stigmatisering, relaties tussen gezonde en riskante werelddelen. Op basis van mijn onderzoek stel ik voor om meer aandacht te besteden aan de politiek, economische en sociale infrastructuren die door AMR in het leven zijn geroepen. Een transdisciplinaire benadering is daarbij noodzakelijk. 